Joanna Getka

Uniwersytet Warszawski

j.getka@uw.edu.pl

\title{
Znaczenie ruskojęzycznego drukarstwa bazyliańskiego w rozwoju języka ukraińskiego i białoruskiego ${ }^{1}$
}

Słowa kluczowe: drukarstwo, bazylianie, XVIII wiek, prosta mowa, język ukraiński, język białoruski

Keywords: Basilians' typographies Ukrainian, Belarusian cultures, XVIII century, national languages, prosta mova

The impact of Basilians' printing in Ruthenian language in the development of the Ukrainian and Belarusian languages

Summary: Multilingualism of prints from Basilians' typographies contributed to the rapprochement and interpenetration of cultures of Ruthenian nations (Ukrainians, Belarusians) with Polish and Western European cultures. Especially important in this context was the printing of original and translated works in Ruthenian language (religious and secular texts), similar to the spoken language of that period. This raised the prestige and confirmed the adequacy of this language for the purposes of literature. This was conducive to the development of national languages (Ukrainian and Belarusian).

I. Ze względu na złożoną sytuację społeczną, polityczną i kulturową dopiero koniec wieku XVIII - początek XIX stał się okresem tworzenia narodowych literatur ukraińskiej i białoruskiej (opartych na języku ludowym, potocznym, ,prostym”).

Jako ważny impuls rozwoju literatury ukraińskiej podaje się zazwyczaj wydanie Eneidy I. Kotlarewskiego w 1798 r. oraz twórczość

${ }_{1}$ Badania prowadzone dla potrzeb niniejszej analizy zostały sfinansowane ze środków Narodowego Centrum Nauki przyznanych na podstawie decyzji numer DEC-2012/07/D/HS2/03672. 
I.E. Niekraszewicza. W Galicji początki literatury ukraińskiej wiąże się natomiast z tzw. Ruską Trójcą, ugrupowaniem społeczno-kulturalnym, działającym od 1833 r. we Lwowie ${ }^{2}$. Przy omawianiu historii białoruskiego języka literackiego za prekursorskie w tym kontekście uważa się powstanie utworów anonimowych: Тарас на парнасе сzу Энэьда навывварат ${ }^{3}$, a następnie utworów Jana Barszczewskiego, Hieronima Marcinkiewicza, Aleksandra Rypińskiego, Władysława Syrokomli, Jana Czeczota i innych.

Pierwsze próby kodyfikacji języka ukraińskiego pojawiły się na początku XIX wieku. Wśród jej prekursorów można wymienić Oleksego Pawłowskiego ${ }^{4}$, ale dopiero w 1893 r. wyszła we Lwowie, zatwierdzona przez władze i dopuszczona jako podręcznik szkolny Руска граматика Stefana Smal-Stockiego i Teodora Gartnera. W latach 1907-1909 został opublikowany Словарь украинскаго языка pod redakcją Borysa Hrynczenki, a w styczniu 1919 r. zwołano komisję do spraw ortografii, która opracowała Головніi правила українського правопису. W składzie komisji byli m.in. Agatangel Krymski, Iwan Ohijenko, Jewhen Tymczenko ${ }^{5}$.

${ }^{2}$ Por. np. W. Mokry, Ruska Trójca. Karta z dziejów życia literackiego Ukraińców w Galicji w pierwszej połowie XIX w. Kraków 1997; R. Łużny, Zarys dziejów literatury ukraińskiej, [w:] Ukraina: teraźniejszość i przeszłość, red. M. Karaś, A. Podraza, Kraków 1970; M. Łesiów, Ukraina wczoraj i dziś, Lublin 1995.

3 Autorstwo tych utworów przypisuje się czasem Wincentemu Rawińskiemu, lecz w pełni nie jest to dowiedzione. Szerzej: Б. Плотнікаў, Беларуская мова. Лінгвістычны кампендыум, Mińsk 2003, s. 64 i nast. Тарас на парнасе сzу Энэыда навыварат nie są zresztą utworami najstarszymi - wcześniej pojawiały się anonimowe wiersze i gawędy, np., Уваскрашэнне Хрыстова і сашэствіе яго ў ад, Тэатр, Праўда, Вясна, холад, перапала, Вось, які ияпер люд стаў, Гутарка Даніль са Сияпанам. Wśród wspomnianych utworów język Tarasa na parnasie jest najlepiej opracowany. Por. Л.М. Шакун, Гісторыя беларускай літаратурнай мовы. Мінск 1966, s. 47. Podobnie było na ziemiach ukraińskich - twórczość indywidualną poprzedziło szereg utworów anonimowych. Por.: В.М. Русанівьский, Історія української літературної мови. Київ 2002, s. 151.

4 О. Павловський, Граматика Малороссійсскаго наргчия..., St. Petersburg 1818. Próby wprowadzenia ortografii na zasadach fonetycznych przedsięwziął również m.in.: J. Żelechiws'kyj, co odzwierciedlają zapisy w słowniku jego autorstwa (por. Є Желехівський, Малоруско-німецький словар, Lwów1886 r.). 5 Za: I. Огієнко, Нариси з історії украӥнської мови: система украӥнського правопису, Warszawa 1927, s. 10 Agatangel Krymski 12. 
W przypadku języka białoruskiego pierwszą gramatyką była Бeларуская граматька для школ Bronisława Taraszkiewicza, wydana w 1919 r. w Wilnie. Próby opisu języka rozpoczął Jefim Karski (jego genialna monografia Белорусы stała się podstawą rozwoju białoruskiej lingwistyki). Istotna w tym kontekście była działalność Iwana Nosowicza, który opracował Словарь белорусского наречия 6 , a także rola pierwszych białoruskich gazet: Наша Доля (1906) і Нама Ніва (1915).

Wcześniejsza, osiemnastowieczna literatura ukraińska, będąca domeną warstw oświeconych, nie uznawała języka prostego jako pełnoprawnego języka wypowiedzi literackiej. Był on, w zależności od autora i sytuacji, uznawany za dialekt języka polskiego bądź rosyjskiego.

Pojawiające się teksty w języku prostym można było znaleźć jedynie w literaturze tzw. niskiego stylu: poezji burleskowo-trawestacyjnej, pisanej przez wędrujących diaków czy w interludiach i intermediach - scenkach wystawianych w przerwach dramatów szkolnych, służących rozładowaniu napięcia.

W efekcie, język prosty, a więc potoczny język białoruski i ukraiński, choć na co dzień był głównym środkiem komunikacjī, ze względu na fakt, że nie cieszył się prestiżem, początkowo nie był wykorzystywany do potrzeb kościelnych (w liturgii), literackich i edukacyjnych. Pod koniec XVIII w. w Galicji doszło do skomplikowanej sytuacji wielojęzyczności - greka, łacina i cerkiewnosłowiańszczyzna obsługiwały język pisany (piśmiennictwo religijne, nauka), a w ko-

\footnotetext{
${ }^{6}$ И. Носович, Словарь белорусского наречия, St. Petersburg 1870. Pracy nad słownikiem Nosowicz poświęcił około 20 lat. Jak zauważył S. Stankiewicz, ten słownik XIX-wiecznego języka białoruskiego był pierwszym, a zarazem dogłębnym opracowaniem w dziedzinie białoruskiej leksykografiі які адлюстраваў багацьце лексічных рэсурсай гутарковай беларускай мовы. Р. Шарупіч (pseudonim S. Stankiewicza), На стогоддзе беларускага слоўніка, „Беларус” 169/1971, s. 2; za: Н. Баршчэўская, Беларуская эміграцыл - абаронца роднае мовы. Варшава 2004, s. 228.

${ }^{7}$ W. Witkowski, Język utworów Joannicjusza Galatowskiego na tle języka piśmiennictwa ukraińskiego XVII wieku, Kraków 1969, s. 15.
} 
munikacji ustnej aktywnie używane były mowa polska, niemiecka (co miało uzasadnienie praktyczne) i ruska (prosta) ${ }^{8}$.

Zmiana tej sytuacji dokonywała się powoli, zaś dużą zasługę w tym procesie mają typografie bazyliańskie.

II. Choć jest oczywiste, że języki białoruski i ukraiński stanowią dwa odrębne systemy w grupie języków wschodniosłowiańskich, pojęcie ,prosta (ruska) mowa” odnosi się w równym stopniu do obu $\mathrm{z}$ nich. Jest to spowodowane wielowiekowym wspólnym rozwojem literatury białoruskiej i ukraińskiej, co dało podstawy do wydzielenia wspólnego dla tych języków zachodnioruskiego obszaru kulturowego $^{9}$. Nie znaczy to bynajmniej, że język tekstów powstałych na ziemiach etnicznie białoruskich i ukraińskich jest jednakowy. Wyraźnie zaznaczone są wybrane cechy językowe danych języków, ale dopiero dogłębna analiza języka tych utworów za pomocą metod statystycznych pozwala w miarodajny sposób ustalić substrat etniczny prostej ruskiej mowy ${ }^{10}$.

\footnotetext{
${ }^{8}$ R. Radyszewśkyj, Polskojęzyczna poezja ukraińska od końca XVI do poczatku XVIII wieku, cz. 1. Monografia, „Prace Komisji Historycznoliterackiej”, Kraków 48/1996, s. 9-10, S. Kozak Polacy i Ukraińcy. W kręgu myśli i kultury pogranicza. Epoka romantyzmu, Warszawa 2005, s. 17

${ }^{9}$ Proponowany termin zachodnioruski jest pochodną binarnej klasyfikacji wschodniosłowiańskiego obszaru językowego zaproponowanej przez Leszka Bednarczuka, zgodnie z którą w ramach językowego obszaru słowiańszczyzny wschodniej należy wyróżniać grupę „wschodnioruską” (uformowaną na terenie Wielkiego Księstwa Moskiewskiego - Rusi Moskiewskiej), reprezentowaną przez język rosyjski i „zachodnioruską” (formowaną na Rusi Halicko-Wołyńskiej, w Wielkim Księstwie Litewskim i Rzeczpospolitej (Rusi Litewskiej i Koronnej). Grupa „zachodnioruska" - co zrozumiałe - rozpada się na dwie podgrupy: północną - białoruską i południową - ukraińską, por.: L. Bednarczuk, Czy istnieją języki zachodnioruskie?, [w:] Polsko-białoruskie związki językowe, literackie, historyczne i kulturowe, M. Kondratiuk, B. Siegień (red.), Białystok 2004, s. 138.

10 Szerzej na ten temat patrz: Białoruski? Ukraiński? Uwagi o metodologii klasyfikacji źródet powstałych na ziemiach białoruskich i ukraińskich w XIV-XVII $w w .$, ,Studia Interkulturowe Europy Środkowo-Wschodniej” 4/2010, s. 50-67.
} 
III. Dążenie do sytuacji, w której ogólnodostępny język stanowi podstawę języka literackiego jest zrozumiałe, a tendencje do tworzenia literatur w językach narodowych widoczne są w kulturze europejskiej już od czasów Odrodzenia. Na ziemiach ukraińskich i białoruskich proces ten dokonywał się później i wolniej, a znaczną rolę odegrało tutaj drukarstwo. W tym kontekście na szczególną uwagę zasługuje drukarstwo bazyliańskie. Zakonnicy osadzeni w miejscowej rzeczywistości i rozumiejący pilną potrzebę druku ksiąg w języku powszechnie używanym przez odbiorców wpłynęli na proces formowania się współczesnych języków literackich białoruskiego i ukraińskiego, a także położyli podwaliny pod kształtowanie się tożsamości tych narodów. Systematyczna praca, bezpośredni kontakt z wiernymi gwarantowały nie tylko możliwość poznania ich potrzeb, ale przede wszystkim stałe oddziaływanie na nich. Jak wynika z treści bazyliańskich wydań teologii moralnej, praca z wiernymi polegała na tłumaczeniu zasad wiary i Dekalogu tak w odniesieniu do religii, jak również do pożądanych przez Kościół postaw społecznych. Rola drukarstwa wychodzi poza sferę edukacyjną i kulturotwórczą, a staje się również socjotwórczą. Z drugiej strony drukowanie tekstów w języku ruskim miało znaczenie utylitarne: księgi w języku zrozumiałym dla wiernych miały na celu utrwalanie efektu misji bezpośredniej.

Liczne wydania w języku ruskim sugerują, że bazylianie dążyli do zmiany statusu języka ruskiego i popularyzowali go jako w pełni odpowiedni do potrzeb kulturowych. Niejednokrotnie dawali temu wyraz i to nie tylko w przedmowach do swoich wydań, ale również w praktycznych poradach. Z jednej strony potoczną ruszczyznę traktowali jako równoprawny z polszczyzną środek komunikacji z duchownym (ergo - sferą sacrum: Bogiem). W wydaniach teologii moralnej przy okazji omawiania kwestii spowiedzi zaznaczono, że wierny może relacjonować swoje grzechy zarówno po polsku, jak i po rusku. Gdy ktoś nie umiał spowiadać się w jednym z tych języków sugerowano 
mu spowiedź przez tłumacza ${ }^{11}$. Tego typu wypowiedzi świadczą o równoprawnej pozycji obu języków. Co więcej - zgodnie z założeniami przekazywanymi we wspomnianych wyżej przedmowach - druki te miały pełnić rolę elementarzy do nauki języka ruskiego.

Działania bazylianów uwzględniające zapotrzebowanie czytelników w kwestii języka dzieł były świadome, o czym oprócz statystyk wydań (w zakładach typograficznych usytuowanych na północno-wschodnich rubieżach dawnej Rzeczypospolitej w Wilnie i Supraślu wychodziło więcej tekstów polskojęzycznych, co było spowodowane polonizacją tych ziem; na południowym wschodzie zaś wydawano większość tekstów czcionką cyrylicką - w języku cerkiewnosłowiańskim i ruskim/prostym) $)^{12}$, świadczą o tym przede wszystkim przedmowy do ich ruskojęzycznych wydań, niezależnie od ich przynależności do nurtu literatury religijnej czy świeckiej. Wynika z nich, że zależało im nie tylko na wydawaniu książek w języku zrozumiałym przez ich czytelników, ale również - co nawet ważniejsze - propagowaniu języka ruskiego, zapisanego alfabetem cyrylickim. Sugerowali bowiem, że ich teksty mogą - i powinny - służyć jako podręczniki, pomoce do nauki czytania, czyli pełnić rolę podobną do rzymskokatolickich katechizmów.

IV. Źródło do badań w ramach niniejszego artykułu stanowią ruskojęzyczne druki bazyliańskie z XVIII wieku, bądź wydania z tego

${ }^{11}$ Собранїе прыпадковъ краткое и дух[о]внымъ особамъ потребное имьщее въ себь науку о сакраментахъ, о десати Б[ж]їих приказаняхъ о приказаняхъ иерковныхъ и о науци хрїстїанской съ выкладомъ молитвы Отче нашъ и В[о] (2)[о]родыце Дьво иль исповьданыя Вирь православнія католичискї..., Supraśl 1722, s. 39; Собраніє припадков краткое и духовным особам потребноє. Имущее в себь науку о сакраментах, о десяти божіих приказанях, о приказанях иерковных и о науці христіанской, с выкладом символа, или исповьданія віры православныя кафолическія, с выкладом молитвы: отче наш и богородице дьво. Такожде науку како подобает наставляти мальх или невіжов в вьры православной содержащее, Uniów 1732, s. 39v.

12 J. Getka, Polskojęzyczne druki bazyliańskie (XVIII w.), Warszawa 2013, s. 248. 
okresu, zawierające elementy pisane w języku ruskim. Znajdują się wśród nich teksty reprezentujące różne gatunki i style. Literatura, głównie religijna - poradniki, modlitewniki, katechizmy, etyki chrześcijańskie, zbiory kazań, proza oratorsko-kaznodziejska, podręcznik teologii, pieśni, utwory poetyckie - w sposób przystępny miała wyjaśniać zagadnienia teologiczne, odnosząc je do problemów życia codziennego. Wśród bazyliańskich wydań ruskojęzycznych znaleźć można również teksty o tematyce świeckiej: dokumenty oraz poradniki, dotyczące różnych dziedzin życia, zarówno prowadzenia gospodarstwa, jak i zachowania w towarzystwie.

Kryteriami doboru źródeł był ich język i przynależność do bazyliańskiej produkcji typograficznej. Drukarstwo w języku prostym jest nieodłącznym elementem pracy drukarzy bazyliańskich w ciągu całego okresu unickiego wybranych typografii. Jest ono ważnym źródłem poznania rozwoju prostej mowy i świadectwem stopniowego przejmowania przez nią kolejnych elementów życia społecznego, co należy wiązać z rozprzestrzenianiem idei Oświecenia zjednej strony, z drugiej zaś - początkiem odrodzenia narodowego.

V. Druk ksiąg w języku ruskim był związany z konstytutywnym zadaniem bazylianów - misjami. Zakonnicy dążyli do bezpośrednich kontaktów i chcieli być zrozumiani przez wszystkich swoich odbiorców, co wymuszało poszukiwanie skutecznej drogi kontaktu z często niewykształconymi wiernymi. Dlatego kazania musiały cechować się prostotą wywodu, który do tego byłby na tyle obrazowy i przekonywujący, by pobudzać do pracy nad sobą, ponieważ nie z słów wybornych, ani z rhetoryczney mowy pozna się, ale z prostego a nabożnego sensu, który nie stuch grzeje, lecz zapala serca, dusze posila; nie rozum szkodliwemi ładuje ciekawościami. Ta książka wiedzie do zakopanego na niwie skarbu, to iest do zakrytey w Ewangieliey, nauki Chrystusowey, do wiaryżywej ${ }^{13}$.

${ }^{13}$ Wstęp do czytelnika, [w:] Zorza jasna, Świat Ewangelskich promieni świattem oświecająca ludzi trojakiego stanu duchowego, świeckiego y zakonnego do 
W sytuacji lingwokulturowej dawnych wschodnich ziem Rzeczypospolitej należało uwzględniać również kwestię wielojęzyczności. W wyniku zróżnicowania dialektalnego obszaru języków wschodniosłowiańskich, cerkiewnosłowiański język liturgiczny stał się z biegiem czasu niezrozumiały nie tylko dla parafian, ale także i duchowieństwa, co podkreślają już ówcześni autorzy ${ }^{14}$.

Podjęcie decyzji o druku w języku potocznym nie było jednak zapewne łatwe ze względu na szereg czynników. Język prosty w końcu XVIII - na początku XIX wieku, jak już była mowa, nie cieszył się wysokim prestiżem, ale ze względów praktycznych istniała paląca potrzeba tłumaczenia na prosty język modlitw i innych tekstów. W Trebniku poczajowskim z 1741 roku czytamy, że mądry duchowny podczas sakramentu namaszczenia chorych dialog z wiernym, a także wszystkie modlitwy odprawia w prostym języku ruskim (Сїя и инья краткїя стїхи и Молитвы мудрый Іерей наученному словенскимъ простому же умирающему, простым рускимъ языкомъ да предводит $\left.{ }^{15}\right)$.

Cel nauczania w języku prostym wyłożył misjonarz Hieronim Kaletyński, ieromonach ihumen klasztoru brackiego krzemienieckiego w dedykacji do metropolity Sylwestra Lubienieckiego Rudnickiego umieszczonej w pierwszym wydaniu Narodowieszczania (1765). Pod-

doskonałości chrześcijańskiej wiodąca przez pewną osobę Bazylego s. Zakonu wedtug porządku Cerkwi Greckiey na widok wystawiona y pokazana swiatu, Supraśl 1708, s. 2, rękopis № 3, teczka rękopisów (MW) MB152, Biblioteka Narodowa im. W. Stefanyka, za: O.P. Marcelu OSBM, Bazylianie w kościele unickim i ich misja ludowa, [w:] Dziedzictwo unii brzeskiej, R. Dobrowolski, M. Zemło (red.), s. 59-80, s. 77.

${ }^{14} \mathrm{~W}$ przedmowie do przekładu Ewangelii Wasyl Ciapiński twierdzi, że duchowni najmniej (cerkiewny) rozumieja, nawet się go nie uczą. Za: A. Brückner, Dzieje kultury polskiej, t. 2, Warszawa 1958, s. 359. Z kolei w przedmowie do wydanego w Supraślu w 1722 r. słownika (Лексикон сиреч словесник славенский, имеюш в себе словеса первее Славенския, Азбучныя, посем же Польския) stwierdzono, że dany leksykon wydrukowano z myślą o kandydatach do stanu duchownego Cerkwi Unickiej, gdyż „ledwo co setny” rozumie język cerkiewnosłowiański, co więcej - wielu spośród ,jerejew” nie wie, co czyta! Za: Z. Jaroszewicz-Pieresławcew, Druki cyrylickie z oficyn Wielkiego Księstwa Litewskiego w XVI-XVIII wieku, Olsztyn 2003, s. 191.

${ }^{15}$ Trebnik, Poczajów 1741, k. 158. 
kreślał, że każdy kaznodzieja powinien mówić do wiernych w sposób zrozumiały i prosty, bowiem nauka wiernych nie ma na celu prezentacji własnego kunsztu oratorskiego, ale korzyść zbawienia dusz słuchających i stosujących się do nauk wiernych (Каждаго хрїстїанскаго Проповъдника оурадь есть, и повинность, не хитрословӥи Риторскими въщчати, но простою бесъдою о повинностехъ христїанскихъ, о воли, и заповъдехъ Божїхъ, простихъ людей поучати. Ибо и премудргйшїи оучителе, не преходящой славы и остроуї и добровпщанїя своего, но ползы и приобргтенїя къ спасенїю душъ христїанскихъ uщymъ $)^{16}$. Było to zresztą powtórzenie tez, pojawiających się już w tekstach z XVII wieku ${ }^{17}$.

Wskazanie konieczności mówienia nie językiem ozdobnym i wyszukanym, ale prostym, trafnym i jasnym stanowi zarazem odpowiedź na pytanie o przyczyny druku książek o charakterze dydaktycznym, moralizatorsko-nauczającym, pisanych простим язиком простійшаго ради іже по всех народа ${ }^{18}$. Pierwotnie tłumaczenie to wykonywał każdorazowo kapłan odprawiający posługę. Zamieszczenie tych fragmentów w języku ruskim w księgach o charakterze liturgicznym miało niebywałe znaczenie dla podniesienia prestiżu tego języka.

Bazylianie wydali po rusku kilka tego typu tekstów o charakterze moralizatorsko-nauczającym, każdy z nich był kilkukrotnie przedrukowany. Najbardziej potrzebna i popularna okazała się Teologia Moralna. W zależności od czasu i miejsca wydania miała różne tytuły

\footnotetext{
${ }^{16}$ Слово къ народу кафоліческому, Poczajów 1765, dedykacja.

${ }^{17}$ W zbiorze kazań Ключ разуменія... (1659), karta 244b, Joannicjusz Galatowski pisał: Staraj się, żeby wszyscy ludzie zrozumieli to, co mówisz na kazaniu. Bo [...] jeśli będziesz głosit słowo boże, tak, że nikt jego nie zrozumie, siebie samego będziesz wystawiat, a nie stowo boże, za: В. Передрієнко, Формування украйнської літературної мови ХVIII ст. на народної основі, Kijów 1979, s. 61.

${ }^{18}$ Сьмя слова Божія на нивь сердеи... человьческих сьяного, си есть ... на недыли... і праздники... поученія от іноков Почаєвського монастиря із различних авторов давніх же і настоящих проповьдовавших... простим язиком простійшаго ради іже по всех народа сложенная, Poczajów 1772, 1781.
} 
(Собраніе прыпадковъ краткое и дух[о]внымъ особамъ потребное, Supraśl 1722, Uniów 1732, Поученіе о с[вя]тих тайнах, о добродьтелех б[о]гословских..., Uniów 1745, Богословіа нравоучителная, Poczajów 1751, 1756, 1787) ${ }^{19}$; była publikowana również we fragmentach (Краткое сословіе науки хрістіанскія..., Supraśl 1756 ${ }^{20}$. Dwukrotnie ,po naszemu” były wydane Nauki Parafialne (Науки парохіальнія на недбли и свята урочистия ињьлого року,

${ }^{19}$ Собраніе прыпадковъ краткое и дух[о]внымъ особамъ потребное имбщее въ себь науку о сакраментахъ, о десати Б[ж]їих приказаняхъ о приказаняхъ иерковныхъ и о науци хрїстїанской съ выкладомъ молитвы Отче нашъ и В[о](2)[о] родыце Дьво иль исповьданыя Вирь православнія католичискїя..., Supraśl 1722, Собраніє припадков краткое и духовным особам потребноє. Имущее в себь науку о сакраментах, о десяти божіих приказанях, о приказанях иеерковных и о науці христіанской, с выкладом символа, или исповьданія віры православныя кафолическія, с выкладом молитвы: отче наш и богородице дьво. Такожде науку како подобает наставляти мальх или невіжов в вьры православной содержащуее, Uniów 1732, Поученіе о с[вя]тих тайнах, о добродьтелех б[о] гословских, о заповьдех Б[о]жїхъ, з заповьдех иерковніхъ, о грбхахъ, о казнехъ и карахъ и [е]рковніх': С пріложеніем обичной наукы о догматах вьры кафолической въ кратиь собранное: Особом д[y]ховнӥмъ, найпаче же презвитеромь парохїалнїмъ благопотребное, Uniów 1745, Богословіа нравоучителная, содержашая в себь собраное вкратиь поученіе о святых тайнах, о добродытелях богословских, о заповьдех Божиих, о заповьдех ияерковных, о грбхах, о казнех и карах церковных с приложеніем обычныя науки о догматах веры кафолическія, и лексікона славенско - полскаго..., Росzајów 1751, Богословіа нравоучителная, содержащая в себь собраное вкратиь поученіе о святых тайнах, о добродытелях богословских, о заповьдех Божиих, о заповьдех иерковных, о грбхах, о казнех и карах иерковных с приложеніем обычныя науки о догматах веры кафолическія, и лексікона славенско - полскаго, особам духовныл, наипаче пресвитерам парохиалным благопотребное, в монастире Почаевском Чина Святаго Васіліа Великаго Року от воплощения Христова 1756 типом изданая, Рoczajów 1756, Богословия нравоучителная, содержащуая в себе собраное вкратие поучение о святых тайнах, о добродетелех богословских, о заповедех божиих, о заповедях ичерковных, о грехах, о казнех сиречь карах ичерковных, с приложением обычныя науки о догматах веры кафолическия и некоторых ведомостей особам духовным, наипаче же пресвитером парохиалным благопотребное, Poczajów 1787.

${ }^{20}$ Краткое сословіе науки хрістіанскія катофическомучеловекумногополезное и потребное, Supraśl 1756. 
Poczajów 1794, 1797) Juliana Dobryłowskiego ${ }^{21}$, trzy razy poradnik misjonarski Stowo do ludu katolickiego (Народовещание или Слово к народу кафолическому..., Poczajów 1765, 1768, 1778) ${ }^{22}$, raz podręcznik dogmatyczno-moralny Fiodora Besarabskiego (Писмена..., Poczajów 1771) $)^{23}$. Po rusku wydawano również katechizmy: w 1788 roku ukazało się w Poczajowie Оглашеніе си есть катехизмъ мъстьонарскій Монаховъ Чина ст. Васілїя великаго вкратиґъ собранъ... (dalej: Katechizm misjonarski...) wydane „ku pożytkowi go czytających i słuchających", w Supraślu zaś dwujęzyczny tekst Najpospolitsze y nayistotnieysze nauki chrześcijańsko-katolickiey religii (1788).

Jako język potoczny, prosta mowa nie była kodyfikowana. Nastręczało to wielu problemów redaktorom tekstów: wspomniany wyżej Fiodor Besarabski zauważa, że zupełnie innym doświadczeniem jest

\footnotetext{
${ }^{21}$ Науки парохіальнія на недбли и свята урочистия ияблого року ... 3 славенскорускаго на простый и посполитий язик рускій преложенія, Росzајо́w 1792 і Науки парохіалнія на недбли и свята урочистья ияблого року ... з приданієм при конць науки при шлюбь, двох наук при погребеніи ... з славенско-рускаго на простый и посполитый язык рускій преложеннія, Росzајо́w 1794.

22 Слово к народу кафолическому чрез монахов чина св. Василія Великого в провьниіи Полской званію катихистічному прилежающих в повьть Кременецком року... 1756 проповьданое, Росzајо́w 1765; Народовещание или слово к народу кафолическому чрез монахов чина святаго Василіа Великаго в провинции Полской званию катихистичному прильжаших в повьть Кременеиком, 1756 года проповеданое. Второе се, с прилежньйшем во исправленіи опаснством, ещуе же і пространным о обрядех христіанских, от достовьрных писателей собранным новоприложеніем..., Росzајów 1768; Народовещание или Слово к народу кафолическому..., Poczajów 1778) i dwóch wydań Ziarna Słowa Bożego: Сьмя слова божія на нивь сердец человьческих си есть изряднейшаяча недьли всего льта поученія иноков Почаевскаго монастира из различних авторов давніших же и настоящо проповьдавших, прежде со бранная, нынь же с приложат.ч и на праздники обновленная по благословению его преосвященства Кир Киприана Стеикаго, екзарха митрополии Киевския, Галиикия, и всея России, Луцукаго и Острогскаго Епископа, таже в душеспасителную чтущьым и послушающым ползу типом изданная в типографии Почаевской Ч.С.В.В.

${ }^{23}$ Ф. Басарабський, Писмена си єсть Начатки догмато-нравоучителныя богословіи, Poczajów 1771.
} 
wykładanie i nauczanie wiernych po rusku, a zupełnie czym innym spisanie swoich myśli w tym języku. Stąd wniosek, że autorzy zdawali sobie sprawę nie tylko z potrzeby tłumaczenia tekstów na ruski, ale również ze związanymi z tym trudnościami: по силь моей начну писати Русскимь Языкомь (бо еже множайшымь оу нась оугодну сему быти) ${ }^{24}$.

Niezależnie od problemów, jakie sprawiał druk ksiąg w nieskodyfikowanym języku prostym, bazylianie uważali język cerkiewnosłowiański za mniej im właściwy. W nieanalizowanej w niniejszej pracy ze względu na cerkiewnosłowiański język wydania innej edycji teologii moralnej: Bogosłowia nrawouczytelnogo $(1776)^{25}$ proszą czytelników o pomoc i wskazanie ewentualnych błędów, które poprawią przy kolejnym wydaniu książki: Ниже бо когда якїй либо от иностраннаго языка первшїй преводь по всему совершень бываеть, ниже мы въ славяно-рускомъ языцъ совершенно искусныхъ себе быти знаемъ ${ }^{26}$. Język cerkiewnosłowiański określają tu jako sztuczny. Stąd wniosek, że cechowała ich świadomość sytuacji socjolingwistycznej.

Nieco łatwiej było zapewne wydawać teksty o przeznaczeniu świeckim, nie było tu bowiem pokusy ulegania tradycji piśmiennictwa cerkiewnosłowiańskiego. W Poczajowie ukazały się dwa

\footnotetext{
${ }^{24}$ Ф. Басарабський, Писмена си єсть Начатки догмато-нравоучителныя богословіи, Poczajów 1771, wstęp, s. 14.

25 П.Г. Антоіне, Богословіе нравоучителное повсемственное, честнымъ отцемъ Павломь Гаврїиломь Антоіне Пресвутеромъ и оучителемъ ст. Богословія, перве латинскимъ диалектомъ потонку исписанное, Многажды в ползу Парохомъ и Духовникомъ Тупомъ издаваемое, Ново монахами чина святаго Васіліа Великаго на русскій діалект преведеное и во оудобное наставитися от него хотящимї оупотребленїе, по засвидьтелствованїю Богослововъ, и произволенхю Начальствующихъ Таже по Благословленїю его преосщенства Киръ Сvлвестра Лубіеніеикаго Руднбикаго, Ез̆арха всея России, Луцчкаго, и Острогскаго Епископа ОрдінаС(вя)таго Станїслава Кавалера напечатаное, Том а, заключаюй' в' себь Разглаголствїя д: а. о совести, б. о законахъ, г. о грехахъ, д. о добродетелехъ Богословскихъ, Росzајów 1776.

${ }^{26}$ Ibid., k. 236v.
} 
tego typu teksty, oba o charakterze poradników, ale z różnych dziedzin życia: prowadzenia gospodarstwa (Książka lekarstw końskich / Книжиия для господарства ${ }^{27}$ ) i dobrego wychowania (Polityka świeck ${ }^{28}$ ). Wydania świeckie potwierdzają tezę o świadomej popularyzacji języka ruskiego jako języka druków, tj. pisanej wersji języka komunikacji. Potwierdza to z kolei, że bazyliańskie podejście do ruszczyzny nie było czysto utylitarne - nie traktowano jej wyłącznie jako instrumentu propagowania dogmatów greckokatolickich wśród nieoświeconego ludu.

W języku ruskim ukazywały się również krótsze dokumenty, umieszczone jako elementy większych wydań (treść uchwały Synodu Brzeskiego z 1596 r. w zbiorze dokumentów Bullae et Brevia Summorum Pontificum Sacrarum Congregationum Decreta..., Poczajów 1767), a także literatura piękna. Do takiej należy zaliczyć wiersz Iwana Wieliczkowskiego Анна Ми Mamu z Molitosłowa z 1755 roku $^{29}$ oraz pieśni. Publikowano je jako aneksy do poszczególnych ksiąg (np. do kolejnych wydań Słowa do ludu katolickiego..., Poczajów 1765, 1768, 1778, Katechizmu misjonarskiego... (1788), Pouczenia chrześcijańskiego... (1790) czy Góry Poczajowskiej) lub większe całości w ramach jednego wydania (np. Pieśni nabożne na missyach zwyczayne załączone do Methodus Peragendi Missiones... 1772 $2^{30}$ ) czy wręcz osobno w Poczajowie wydano Pieśni o Bogurodzicy (Птьсни

\footnotetext{
${ }^{27}$ Книжиця для господарства, указующая, якъ ратовати въ хоробахъ всякую скотину, то есть: конъ, воли, въвцъь, козы, свинг, якъ бълити полотно, якъ боронити пашнъот саранчи, як ратовати ся от джуми, якъ губити гуселницю от капусти, якъ ловити рибу, якъ губити мыши и щург, якъ ратовати скажени собаки, якъ ратовати людій, которихъ собаки скаженіи покусали, якъ ратовати человъка, который не въ давномъ времени зъ ума зыйдетъ, Poczajów 1788.

${ }^{28}$ Польтика свъцкая от иностранныхъ Аvторовъ вкратц̧ъ собранная. Младымъ приличная, встьм же о́бщсе благопотребная..., Poczajów 1770.

${ }^{29}$ Молитвослов. В'немъ же чинъ Часовъ Ц[е]кровныхъ..., Почаїв 1755.

${ }^{30}$ Pieśni nabożne na missyach zwyczajne, [w:] [Sroczyński Cornelius], Methodus Peragendi Missiones apostolicas in Provincia Rutena..., Poczajów 1772, s. 104-116.
} 
о Пре[чи]стьй Б[о]городицй, Poczajów 1773), czy wielokrotnie wznawiany Bohohłasnyk (Богогласникъ... pierwsze wydanie 1790).

Po rusku ukazywały się również drobne wstawki, fragmenty w tekstach pisanych z założenia językiem cerkiewnosłowiańskim. Takie elementy (modlitwy, zwroty, wskazania) pojawiają się w kolejnych wydaniach na temat obrzędu przyjęcia nowicjusza do stanu mniszego pt.: Посльдованіе постригу двою $1750^{31}$ i $1793^{32}$ czy w katechizmie z 1788 roku Поученіе христианское, си есть катехизм вкратиь собранный... Teksty przysiąg, rozmów z parochem pojawiały się w trebnikach, akatystarzach oraz w swoistym poradniku dla parochów, pt. Чинъ Іерейскаго наставленїя в пути вьчныя жизни бользнующихх, Poczajów 1776.

Zamieszczanie w tekstach wydanych z założenia w języku cerkiewnosłowiańskim fragmentów w języku ruskim świadczy o obecności prostej mowy w Cerkwi greckokatolickiej, mimo że oficjalnym językiem liturgii pozostawała cerkiewszczyzna. Sam fakt wydania księgi liturgicznej w tym języku wcale nie oznaczał pełnego monopolu cerkiewszczyzny w kontaktach człowieka z Bogiem, o czym świadczą między innymi słowa z cytowanej wyżej przedmowy do Trebnika z 1741 roku o konieczności przekładu modlitw wiernym na język prosty, którego - jak wspomniano - dokonywał każdorazowo kapłan odprawiający posługę. Zamieszczenie fragmentów tłumaczonych na język ruski w księgach o charakterze liturgicznym miało niebywałe znaczenie dla podniesienia jego prestiżu.

\footnotetext{
${ }^{31}$ Посльдованіе постригу двою: В искус, си есть в малый иноческий образ, и в великий чина иже въ стӹ Еже есть къ оббтомь иноческим, нищеть, послушанӥю, чистоть самоволное оусердїе. Въ Обители Почаевской..., 1750; autorzy sugerują, że było jeszcze trzecie - pierwsze wydanie supraskie tekst, ale nie zachowało się.

32 Посльдование постригу двою в искус, си есть в мальий иноческий образъ и великий чина иже святыхъ Отиа нашего Васїлї Великаго совершенній образъ ..., 1793.
} 
VI. W omówionych wyżej księgach język ruski nie jest jednolity ${ }^{33}$. Jakość odzwierciedlenia cech języka potocznego jest nierówna nawet w kolejnych wydaniach tego samego dzieła. W przypadku edycji Teologii Moralnej czy Słowa do ludu katolickiego może mieć to związek z dążeniem do doprowadzenia tekstu do stanu bardziej „literackiego” poprzez - paradoksalnie - zbliżanie języka do norm cerkiewszczyzny i eliminację cech języka prostego ${ }^{34}$. Decyzja o redakcji mogła być spowodowana tendencją do powrotu do tradycji wschodniej, czego przejawem miało być między innymi posługiwanie się tradycyjnym językiem Kościoła Wschodniego (prawosławnego) ${ }^{35}$.

Analiza tekstów wydanych w XVIII wieku w typografiach zakonnych wykazuje, że bazylianie mieli świadomość filologiczną i działali celowo na rzecz promocji jednego języka literackiego. Zdając sobie sprawę z różnorodności gwar i dialektów języka ruskiego (w ruskiej tej prostej, w Polszcze zwyczajnej i pospolitej biesiadzie, słowa i sposoby ich wyrażenia sa różne i nie dla wszystkich jednakowe: na Wotyniu inne, na Podolu, i na Ukrainie [tj. Kijowszczyźnie - J.G.] inne, na Polesiu inne: wedtug swojego zwyczaju maja ludzie jak gdyby specyficzny tylko sobie język i inny sposób biesiady i słów wyrażenia $\left.{ }^{36}\right)$,

${ }^{3}$ Czasem można doszukać się pojedynczych słów z leksykonu prostej mowy, które w różnym natężeniu pojawiają się w poszczególnych tekstach. Analizie leksyki wydań poczajowskich poświęcona jest niewydana praca doktorska Romana Kisieliowa, por. P.Є. Кисельов, Лексика української мови в почаївських виданнях XVIII - першої третини XIX cm. Автореферат дисертації на здобуття наукового ступеня кандидата філологічних наук, Київ 2005.

${ }^{34} \mathrm{~W}$ związku z tym, co było już sygnalizowane wyżej, mimo podobnego tytułu, trzy wydania Teologii Moralnej nie zostały objęte analizą językową. Są one wydane w języku cerkiewnosłowiańskim: П. Г. Антоіне, Краткое на краткія вопросы... Poczajów 1776, tegoż, Богословіє нравоучителное... Poczajów 1779, tegoż, Богословіє нравоучителноє..., Росzаjów 1793.

${ }_{35}$ Ю.А. Лабынцев, Л.Л. Щавинская, Некоторые обстоятельства и средства поддержания белорусско-украинской униатской литургической практики в XVII - XIX веках, „Древняя Русь” 2/2000, s. 124-136, s. 128 і 129.

${ }^{36}$ Tu i niżej - thumaczenie własne - J. G. w oryginale: ...в руской сей простой, въ Полщьы звычайной и посполитой Бесъдъ слова и способы ихъ вираженїя, суть 
proponują dostosowanie wymowy swojego tekstu do normy miejscowej (łatwo możesz tak im słowa wyrażać, jak oni między soba biesiadować zwykli i jak im jest najmilej, i ku ich pożytkowi najlepiej $\left.b e ̨ d z i e^{37}\right)$. Zabieg ten, choć podobny do typowych zapisów we wstępach do kazań wydanych często w języku cerkiewnosłowiańskim, jest swoistym „krokiem naprzód” na drodze do tworzenia spójnej normy języka pisanego. Teksty bazylianów napisane są już w języku prostym, który cechuje pewien stopień sztuczności i ogólności naddialektalnej, ale wyraźnie widoczne są w nim najbardziej charakterystyczne cechy języka mówionego. Co więcej, prosta mowa wydań poczajowskich zbliżona jest do współczesnego języka ukraińskiego, edycje supraskie zaś cechuje odzwierciedlenie tendencji typowych dla języka białoruskiego. Świadczy to o ewolucyjnym charakterze języka z jednej strony, z drugiej zaś - ewolucyjnym charakterze kultury i literatury.

Podobna tendencja - upraszczania tekstów i ich języka w celu jak najlepszego dotarcia do szerokich rzesz - widoczna jest również w kaznodziejstwie polskim XVIII wieku. Barokowo-wykwintne kazania już przez ówczesnych krytyków odbierane były jako prezentacja możliwości oratorskich mówcy, gdzie efekt oddziaływania kazania usuwał się na drugi plan. Celem było więc pisanie homilii prostszych, nastawionych na zrozumiały i jasny wykład. Problem ten poruszali sami kaznodzieje: ganią oni panegiryczne, rozwlekłe i przez to niejasne wywody, w których ginie zbawienna treść tych wypowiedzi, a które jednak ze względu na wykwintną formę mogły robić wrażenie na słuchaczach ${ }^{38}$. O ile jednak na gruncie polskim

рожнйи и не всъмь единаковїи: на Вольню иншїи, въ Польсю иншӥи, ведлугъ своего звычаю мають люде якобы свойственный свой языкъ, и иншїй способъ бесъды и словъ вираженїя, J. Dobryłowski, Nauki... 1794, wstęp, karty 3-4.

37 Латво можеши сїя краткїя наукы читаючи, так имь слова виражати, якъ они между собою бестдовати обыкоша и якъ имъ прїятнгйше, и ко спасенному пожіткови угоднгйше будетъ. J. Dobryłowski, Nauki... 1794, wstęp, karty 3-4.

${ }^{38}$ Por. M. Borysławski, Kazanie na summie pogrzebowey przed złożeniem do grobu ciała ś. p. JW. Jana Mikołaja Hrabi Chodkiewicza miane, Supraśl 1781. 
zmiany dotyczyły zagadnień stylistyki, to na gruncie ruskim nie było takiej możliwości. Cerkiewszczyzna jako język objawiony ${ }^{39}$ nie mogła podlegać żadnym zmianom, jej styl był sztywny i niezrozumiały. Rusini dysponowali jednak własnym językiem, prostą mowa, który mógł realizować wyżej wymienione cele. Traktowali ten język jako równoważny język literacki.

Działający na specyficznym terenie bazylianie rozumieli złożoność swojego zadania. Wielojęzyczność druków typografii przyczyniła się do zbliżenia i wzajemnego przenikania kultury narodów ruskich (Ukraińców, Białorusinów) z kulturami polską i zachodnioeuropejską. Dodatkowo, oryginalne i tłumaczone dzieła w języku ruskim, zbliżonym do ówczesnego języka mówionego, podnosiły prestiż i potwierdzały adekwatność tego języka dla potrzeb literatury. Sprzyjało to w efekcie rozwojowi języków narodowych (ukraińskiego i białoruskiego).

\section{Bibliografia}

1. Bednarczuk L., Czy istnieja języki zachodnioruskie?, [w:] Polsko-białoruskie zwiazki językowe, literackie, historyczne i kulturowe, M. Kondratiuk, B. Siegień (red.), Białystok 2004.

2. Borysławski M., Kazanie na summie pogrzebowey przed złożeniem do grobu ciała ś. p. JW. Jana Mikołaja Hrabi Chodkiewicza miane, Supraśl 1781.

3. Brückner A., Dzieje kultury polskiej, t. 2, Warszawa 1958.

4. Getka J., Białoruski? Ukraiński? Uwagi o metodologii klasyfikacji źródel powstałych na ziemiach biatoruskich i ukraińskich w XIV-XVII ww., „Studia Interkulturowe Europy Środkowo-Wschodniej" 4/2010, s. 50-67.

5. Getka J., Polskojęzyczne druki bazyliańskie (XVIII w.), Warszawa 2013. Jaroszewicz-Pieresławcew Z., Druki cyrylickie z oficyn Wielkiego Księstwa Litewskiego w XVI-XVIII wieku, Olsztyn 2003.

6. Kozak S., Polacy i Ukraińny. W kręgu myśli i kultury pogranicza. Epoka romantyzmu, Warszawa 2005.

${ }^{39}$ Por. Mentalność rosyjska. Stownik, A. Lazari (red.), Katowice 1995, s. 114-115. 
7. Łużny R., Zarys dziejów literatury ukraińskiej, [w:] Ukraina: teraźniejszość i przeszłość, red. M. Karaś, A. Podraza, Kraków 1970; M. Łesiów, Ukraina wczoraj $i$ dziś, Lublin 1995.

8. $\quad$ Marcel O.P. OSBM, Bazylianie w kościele unickim i ich misja ludowa, [w:] Dziedzictwo unii brzeskiej, R. Dobrowolski, M. Zemło (red.), s. 59-80.

9. Mentalność rosyjska. Stownik, A. Lazari (red.), Katowice 1995.

10. Mokry W., Ruska Trójca. Karta z dziejów życia literackiego Ukraińców w Galicji w pierwszej połowie XIX wieku, Kraków 1997.

11. Pieśni nabożne na missyach zwyczajne, [w:] [Sroczyński Cornelius], Methodus Peragendi Missiones apostolicas in Provincia Rutena..., Poczajów 1772, s. 104-116.

12. Radyszewśkyj R., Polskojęzyczna poezja ukraińska od końca XVI do początku XVIII wieku, cz. 1. Monografia, „Prace Komisji Historycznoliterackiej”, Kraków 48/1996.

13. Trebnik, Poczajów 1741.

14. Witkowski W., Język utworów Joannicjusza Galatowskiego na tle języka piśmiennictwa ukraińskiego XVII wieku, Kraków 1969.

15. Zorza jasna, Świat Ewangelskich promieni świattem oświecająca ludzi trojakiego stanu duchowego, świeckiego y zakonnego do doskonałości chrześcijańskiej wiodacca przez pewna osobę Bazylego s. Zakonu wedtug porzadku Cerkwi Greckiey na widok wystawiona y pokazana światu, Supraśl 1708.

16. Антоіне П.Г., Богословіе нравоучителное повсемственное, честнымъ отцемъ Павломь Гаврїиломь Антоіне Пресвитеромь и оучителемъ cm. Богословія, перве латинскимъ диалектомь потонку исписанное, Многаждь в ползу Парохомъ и Духовникомъ Типомъ издаваемое, Ново монахами чина святаго Васіліа Великаго на русскій діалект преведеное и во оудобное наставитися от него хотящуимї оупотребленїе, по засвидьтелствованїю Богослововъ, и произволенхю Начальствующихъ Таже по Благословленїю его преосщенства Киръ С лвестра Лубіеніецкаго Руднђикаго, Ез̆арха всея России, Луичкаго, и Острогскаго Епископа ОрдінаС(вя)таго Станїслава Кавалера напечатаное, Том а, заключаюй' в себь Разглаголствїя д: а. о совести, б. о законахъ, г. о грехахъ, д. о добродетелехъ Богословскихъ, Росzајо́w 1776.

17. Баршчэўская Н., Беларуская эміграцыя-абаронца роднае мовы. Варшава 2004. 
Басарабський Ф., Писмена си єсть Начатки догмато-нравоучителныя богословіи, Poczajów 1771.

18. Богословіа нравоучителная, содержащая в себь собраное вкратиь поученіе о святых тайнах, о добродьтелях богословских, о заповьдех Божиих, о заповьдех церковных, о грбхах, о казнех и карах церковных с приложеніем обычныя науки о догматах веры кафолическія, и лексікона славенско - полскаго..., Poczajów 1751.

Богословіа нравоучителная, содержащая в себь собраное вкратиь поученіе о святых тайнах, о добродбтелях богословских, о заповьдех Божиих, о заповьдех иерковных, о грбхах, о казнех и карах иерковных с приложеніем обычныя науки о догматах веры кафолическія, и лексікона славенско-полскаго, особам духовным, наипаче пресвитерам парохиалным благопотребное, вмонастире Почаевском Чина Святаго Васіліа Великаго Року от воплощения Христова 1756 типом изданая, Росzајów 1756.

Богословия нравоучителная, содержащая в себе собраное вкратие поучение о святых тайнах, о добродетелех богословских, з заповедех божиих, о заповедях церковных, о грехах, о казнех сиречь карах иерковных, с приложением обычныя науки о догматах веры кафолическия и некоторых ведомостей особам духовным, наипаче же пресвитером парохиалным благопотребное, Poczajów 1787.

19. Желехівський Є., Малоруско-німецький словар, Lwów1886 r.

20. Кисельов Р.С., Лексика української мови в почаївських виданнях XVIII - першої третини XIX cm. Автореферат дисертації на здобуття наукового ступеня кандидата філологічних наук, Київ 2005.

21. Книжсия для господарства, указующая, якъ ратовати въ хоробахъ всякую скотину, то есть: конъ, воли, въвцгь, козы, свинґ, якъ бълити полотно, якъ боронити пашнґот саранчи, як ратовати ся от джуми, якъ губити гуселниџю от капусти, якъ ловити рибу, якъ губити мыши и шург, якъ ратовати скажени собаки, якъ ратовати людій, которихъ собаки скаженіи покусали, якъ ратовати человъка, который не въ давномъ времени зъ ума зыйдетъ, Росzајów 1788.

22. Краткое сословіе науки хрістіанскія катофическому человеку многополезное и потребное, Supraśl 1756.

23. Лабынцев Ю.А., Щавинская Л.Л., Некоторые обстоятельства и средства поддержания белорусско-украинской униатской литургической практики в XVII-XIX веках, „Древняя Русь” 2/2000, s. 124-136. 
24. Молитвослов. В'немъ же чинъ Часовъ Ц[е]кровныхъ..., Почаїв 1755.

25. Народовещание или слово к народу кафолическому чрез монахов чина святаго Василіа Великаго в провинции Полской званию катихистичному прильжаших в повьть Кременецком, 1756 года проповеданое. Второе се, с прилежньйшем во исправленіи опаснством, еще же і пространным о обрядех христіанских, от достовьрных писателей собранным новоприложеніем..., Poczajów 1768.

26. Науки парохіалнія на недьли и свята урочистыя цһблого року ... з приданієм при кониь науки при шлюбь, двох наук при погребеніи ... з славенско-рускаго на простый и посполитый язык рускій преложеннія, Росzајów 1794.

27. Науки парохіальнія на недьли и свята урочистия цьлого року ... 3 славенскорускаго на простый и посполитий язик рускій преложенія, Рoczajów 1792.

28. Носович И., Словарь белорусского наречия, St. Petersburg 1870.

29. Огієнко I., Нариси з історії украӥнської мови: система украӥнського правопису, Warszawa 1927.

30. Павловський О., Граматика Малороссійсскаго наръчия..., St. Petersburg 1818.

31. Передрієнко В., Формування української літературної мови ХVIII cm. на народної основі, Kijów 1979.

32. Плотнікаў Б., Беларуская мова. Лінгвістычны кампендыум, Mińsk 2003,

33. Польтика свъцкая от иностранныхъ Аvторовъ вкратциъ собранная. Младымъ приличная, встьм же о́бще благопотребная..., Росzајów 1770.

34. Посльдование постригу двою в искус, си есть в мальй иноческий образь и великий чина иже святыхъ Отцуа нашего Васїлї Великаго совершенній образъ ..., 1793.

35. Посльдованіе постригу двою: В искус, си есть в мальй иноческий образ, и в великий чина иже въ стызх Ойа ниегго Васілія Великаго совершенный образъ, Еже есть къ обътомъ иноческим, нищеть, послушанїю, чистоть самоволное оусердїе. Въ Обители Почаевской..., 1750.

36. Поученіе ос[вя]тих тайнах, о добродьтелех б[о]гословских, о заповьдех Б[о]жїхъ, з заповьдех иерковніхъ, о грбхахъ, о казнехъ и карахъ и[е] рковніх': С пріложеніем обичной наукы о догматах вьры кафолической въ кратиь собранное: Особом д[у]ховнїмь, найпаче же презвитеромь парохїалнїмь благопотребное, Uniów 1745.

37. Русанівьский В. М., Історія української літературної мови. Київ 2002, S. 151. 
38. Слово к народу кафолическому чрез монахов чина св. Василія Великого в провьнціи Полской званію катихистічному прилежающих в повьть Кременечком року... 1756 проповьданое, Poсzајów 1765.

39. Собраніе прыпадковъ краткое и дух[о]внымъ особамъ потребное имьщее въ себь науку о сакраментахъ, о десати Б[ж]їихъ приказаняхъ о приказаняхъ иерковныхъ и о науич хрїстїанской съ выкладомъ молитвы Отче нашъ и В[о](2) [о]родыце Дьво иль исповьданыя Вирь православнія католичискїя..., Supraśl 1722.

40. Собраніє припадков краткое и духовным особам потребноє. Имущее в себь науку о сакраментах, о десяти божіих приказанях, о приказанях иерковных и о научі христіанской, с выкладом символа, или исповьданія віры православныя кафолическія, с выкладом молитвы: отче наш и богородиие дьво. Такожде науку како подобает наставляти малых или невіжов в вьры православной содержащее, Uniów 1732.

41. СБмя слова Божія на нивь сердеи... человьческих сьяного, си есть ... на недьли... і праздники... поученія от іноков Почаєвського монастиря із различних авторов давніх же і настоящих проповьдовавщих... простим язиком простійшаго ради іже по всех народа сложенная, Poсzајów 1772.

42. СБмя слова Божія на нивь сердец... человьческих сьяного, си есть ... на недьли... і праздники... поученія от іноков Почаєвського монастиря із различних авторов давніх же і настоящих проповьдовавших... простим язиком простійшаго ради іже по всех народа сложенная, Poczajów 1781.

43. Шакун Л.М., Гісторыя беларускай літаратурнай мовы. Мінск 1966. 